\title{
Kalibracja wyników analiz chemicznych piaskowców czerwonego spągowca wykonanych przenośnym spektrometrem XRF
}

\section{Calibration of the results of Rotliegend sandstones chemical analyses performed with a handheld XRF spectrometer}

\author{
Rafał Skupio, Urszula Zagórska, Sylwia Kowalska \\ Instytut Nafty i Gazu - Państwowy Instytut Badawczy
}

\begin{abstract}
STRESZCZENIE: Przenośne spektrometry fluorescencji rentgenowskiej z dyspersją energii (EDXRF) coraz częściej wykorzystywane są do określania składu chemicznego skał na potrzeby przemysłu naftowego. Wyniki badań pozwalają na wspomaganie interpretacji litologicznej lub jej wykonywanie na podstawie modeli mineralogicznych. W przypadku interpretacji ilościowej opartej na wynikach pomiarów przenośnym aparatem XRF wymagana jest wysoka dokładność analiz. W niniejszej pracy przedstawiono problemy, na które trzeba zwrócić uwagę podczas stosowania założonej metodyki pomiarowej, związane głównie z zaniżonymi wynikami dla pierwiastków lekkich (głównych). Testy przeprowadzono na próbkach sproszkowanych, pobranych z rdzeni wiertniczych uzyskanych podczas realizacji otworu wiertniczego ukierunkowanego na skały czerwonego spągowca. Pomiary wykonano przy użyciu spektrometru XRF S1 TITAN firmy Bruker. Przeprowadzone badania dotyczące kalibracji i wprowadzania poprawek pozwoliły na wyeliminowanie dwóch czynników wpływających na niedokładność analiz. Pierwszy z nich to postępujące zużycie lampy rentgenowskiej, które należy sprawdzać poprzez prowadzenie systematycznych pomiarów wzorca. Drugi dotyczy wpływu zmiany gęstości próbki po zmieleniu, co jest istotne w przypadku pierwiastków lekkich (głównie krzemu i glinu), gdyż powoduje obniżenie bezwzględnych wartości w wynikach pomiarów ręcznym aparatem XRF. Z uwagi na rodzaj analizowanego materiału skalnego skupiono się na kalibracji wyników głównych pierwiastków budujących matryce piaskowców czerwonego spągowca. Przedstawiono możliwość kalibracji wyników bezpośrednio w aparaturze, co skutkuje otrzymywaniem skalibrowanych wyników po każdym pomiarze, jak również kalibrację wyników w pliku zewnętrznym. Stosując kalibrację zewnętrzną, można uniknąć błędów spowodowanych zmianą matrycy skalnej, jednocześnie zapewniając możliwość ponownego przeliczenia wyników. Otrzymane współczynniki kalibracyjne znajdują zastosowanie w przypadku skał czerwonego spągowca i wykorzystanego spektrometru XRF z aktualnym oprogramowaniem i kalibracją GeoChem dostarczoną przez producenta. Zmiana któregoś z czynników wymaga przeprowadzenia ponownych badań i rekalibracji wyników. Modele mineralogiczne przygotowane na podstawie analiz XRF mogą być wykorzystane w przyszłości pod warunkiem stosowania odpowiednich współczynników kalibracyjnych.
\end{abstract}

Słowa kluczowe: fluorescencja rentgenowska, spektrometr XRF, kalibracja, skład pierwiastkowy, analizy skał.

\begin{abstract}
Handheld X-ray fluorescence spectrometers with energy dispersion (EDXRF) are increasingly used to determine the chemical composition of rocks for the oil and gas industry. The results of our research allow to create or support the lithological interpretation based on mineralogical models. In the case of quantitative interpretation based on the results of measurements using a handheld XRF device, high accuracy of measurements is required. This paper presents the problems to which attention should be paid when applying the assumed methodology, mainly related to the underestimated percentages for light (main) elements. The tests were carried out on powdered samples of drill cores taken from borehole directed to Rotliegend rocks. The measurements were carried out using Bruker's XRF S1 TITAN spectrometer. The calibration and correction tests led to the elimination of two factors affecting the inaccuracy of the analyses. The first is the progressive aging of the X-ray tube, which should be checked by conducting systematic measurements of the standard reference material. The second concerns the effect of a change in the density of the sample after grinding, which has a significant impact on light elements (mainly silicon and aluminium), causing a decrease in absolute values in the results of measurements using a handheld XRF device. Due to the type of rock material analysed, the focus was on the calibration of the results of the main elements building the Rotliegend sandstone rock matrix. The paper presents the possibility of calibrating the results directly in the device, which results in obtaining calibrated results after each measurement, as well as calibration of results in an external file. By using external calibration, errors caused by changing the rock matrix can be avoided while ensuring that possibility the results can be recalculated. The resulting calibration coefficients are applicable to the Rotliegend rocks and the XRF spectrometer with current software and GeoChem
\end{abstract}

Autor do korespondencji: R. Skupio, e-mail: rafal.skupio@inig.pl

Artykuł nadesłano do Redakcji: 15.05.2019 r. Zatwierdzono do druku: 20.12.2019 r. 
calibrations provided by Bruker. A change in any of the factors requires re-testing and recalibration of the results. Mineralogical models prepared based on XRF analyses can be used in the future, if those appropriate calibration coefficients are used.

Key words: X-ray fluorescence, XRF spectrometer, calibration, elemental composition, rock analysis.

\section{Wstęp}

Przenośne spektrometry fluorescencji rentgenowskiej z dyspersją energii (EDXRF) pozwalają na dokładne określanie składu chemicznego skał w krótkim czasie. Jest to metoda nieniszcząca, umożliwiająca wykonywanie punktowych pomiarów bezpośrednio na rdzeniach wiertniczych lub odsłonięciach skalnych, bez konieczności pobierania próbek (Ogburn et al., 2012). Analizy mogą być wykonywane bezpośrednio na próbkach skalnych, jak i przygotowanych preparatach. W Zakładzie Geofizyki Wiertniczej (INiG - PIB) badania z użyciem przenośnego spektrometru XRF przeprowadza się od końca roku 2013 (Skupio, 2014). Analizy składu chemicznego (XRF) są wykorzystywane do sprawdzania dokładności interpretacji dyfraktogramów rentgenowskich (XRD), realizowanych na potrzeby określania dokładnego składu mineralnego skał zbiornikowych (Kowalska, 2013). W przemyśle naftowym wyniki z pomiarów spektrometrem XRF wykorzystywane są głównie do wykonywania profilowania geochemicznego w otworach na podstawie badań rdzeni lub zwiercin, interpretacji litologicznej (Kowalska et al., 2018), a nawet kierowania trajektorią otworu w trakcie wiercenia (geosteering).

Celem niniejszej pracy jest określenie współczynników kalibracyjnych mających na celu uwzględnianie procesu starzenia lampy rentgenowskiej w uzyskiwanych wynikach, a także wprowadzenie poprawek na obniżoną gęstość próbek sproszkowanych. Wraz ze spadkiem intensywności lampy bieżąca kalibracja jest niezbędna do utrzymania precyzji pomiarów (Panalytical). Analizy wykonano na przykładzie próbek z rdzenia wiertniczego pobranego ze skał czerwonego spągowca stanowiących monotonną sekwencję piaskowcową. Podzielenie profilu czerwonego spągowca na strefy za pomocą analiz składu chemicznego wymaga dokładnych i precyzyjnych pomiarów nakierowanych na zawartości pierwiastków śladowych, które różnicują się w profilu otworu.

Bardzo duży wpływ ma wynik pomiarów składu chemicznego spektrometrem XRF ma gęstość próbki i jej powierzchnia. W przypadku pomiarów prowadzonych na całych rdzeniach lub kawałkach skał wyniki analiz cechują się większym udziałem poszczególnych pierwiastków (suma analizy bliska $100 \%$ ) niż w przypadku pomiarów na materiale sproszkowanym (wynik średnio niższy o 30\%). Spektrometry przenośne są kalibrowane do bezpośrednich pomiarów skał jako metoda nieniszcząca, niewymagająca preparatyki, czego efektem są zaniżone wartości w przypadku pomiarów próbek sproszkowanych. Niestety wykonywanie pomiarów na rdzeniach obarczone jest z kolei błędem pomiarowym związanym z uzyskiwaniem punktowej informacji z obszaru małego pola pomiarowego $\left(0,5 \mathrm{~cm}^{2}\right)$. Błędy te mają źródło w zmiennej wielkości uziarnieniu, różnej porowatości rdzeni oraz nierównościach na ich powierzchni. Wyniki bezpośrednich pomiarów na rdzeniu są zdecydowanie mniej reprezentatywne dla średniego składu skały w porównaniu z próbką skwartowaną i zmieloną. Spektrometr rejestruje zbyt szczegółowe anomalie, takie jak cienkie laminy lub zmiany uziarnienia.

Przez ostatnie lata pracownicy Zakładu przeprowadzili tysiące analiz na różnego typu skałach, tworząc zarówno wiele współczynników kalibracyjnych, jak też modeli mineralogicznych opartych na analizach składu chemicznego (Zagórska et al., 2016). W roku 2017 (po 3 latach intensywnego użytkowania) spektrometr uległ awarii związanej ze zużyciem lampy rentgenowskiej. Jej intensywność spadła, czego efektem było otrzymywanie znacznie zaniżonych wyników. Po naprawie spektrometru oraz przeprowadzeniu przez producenta nowej kalibracji wyniki pomiarów wzorców testowych powróciły do normy.

Otrzymywanie powtarzalnych wyników pomiarów wykonywanych w różnym czasie jest istotne dla badań, w których wykonywane są modelowania składu mineralogicznego (interpretacja litologiczna). Raz zbudowane modele mogą być wykorzystywane dla określonej litologii przez długi czas pod warunkiem zachowania stabilności pracy urządzenia.

\section{Aparatura badawcza i metodyka badań}

Do przeprowadzenia analiz wykorzystano spektrometr fluorescencji rentgenowskiej z dyspersją energii EDXRF S1 Titan wyprodukowany przez firmę Bruker (rys. 1). Skupio (2014) przedstawił dokładny opis używanego spektrometru oraz zasadę jego działania na przykładzie pomiarów skał sylurskich. W aparacie zastosowano metodę parametrów fundamentalnych, umożliwiającą wykonywanie pomiarów bez konieczności wykorzystywania wzorców kalibracyjnych (Loubser i Verryn, 2008; Wieczorek, 2012). S1 Titan został wyposażony w anodę $\mathrm{Rh}$ (o maksymalnych parametrach: $50 \mathrm{kV}, 100 \mu \mathrm{A}, 4 \mathrm{~W}$ ) i detektor $10 \mathrm{~mm}^{2}$ X-Flash ${ }^{\circledR}$ Silicon Drift Detector (SDD), o typowej rozdzielczości 147 eV dla linii Mn K-alfa (Bruker Corporation). Zakres pomiarowy urządzenia pozwala na detekcję pierwiastków od magnezu do uranu (maksymalnie 45 pierwiastków). 
Pomiar jest podzielony na dwie fazy. Pierwsza, z zastosowaniem filtra TiAl i napięcia $45 \mathrm{kV}$, umożliwia pomiary pierwiastków ciężkich. Druga faza, w której napięcie jest obniżone do $15 \mathrm{kV}$, umożliwia pomiary pierwiastków lekkich (głównych). Do przeprowadzenia badań na próbkach skał czas pomiarowy dla pierwszej fazy ustawiono na 60 sekund, natomiast dla fazy drugiej na 240 sekund. Pomiary prowadzono na preparatach sproszkowanych, umieszczonych w pojemnikach z dnem wykonanym z folii polipropylenowej o grubości $6 \mu \mathrm{m}$, która nie ogranicza energii emitowanej przez analizowany materiał.

Poruszony problem zaniżania wyników pomiarów związany jest ze stopniowym procesem spadku intensywności i wydajności lampy rentgenowskiej, spowodowanym degradacją materiałów, z których jest ona zbudowana. W typowych lampach rentgenowskich jest to związane z takimi procesami jak: wypalanie wolframowego filamentu oraz osadzanie zanieczyszczeń na szklanych elementach lampy, rozszczelnienie próżni wewnątrz lampy, co powoduje powstanie łuku wysokiego napięcia i utlenianie materiałów oraz powstawanie pęknięć na anodzie (Spellman High Voltage Electronics Corporation). Wraz ze starzeniem się lampy rentgenowskiej na anodzie pojawiają się pęknięcia o głębokości 5-50 $\mu \mathrm{m}$, co powoduje obniżenie dawki promieniowania średnio o 15\% dla medycznych aparatów rentgenowskich (Mehranian et al., 2010). W spektrometrach fluorescencji rentgenowskiej (WDXRF) starzenie się lampy jest głównym czynnikiem dryftu instrumentalnego.

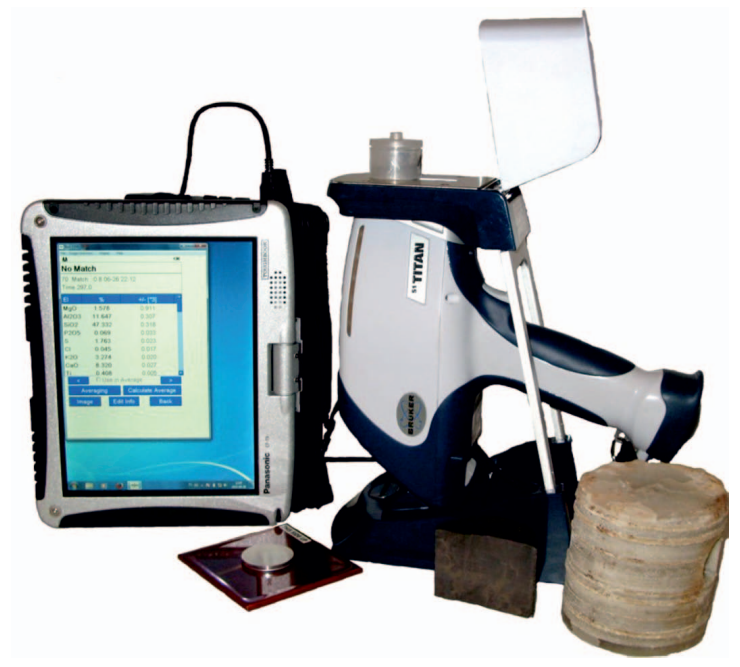

Rys. 1. Spektrometr fluorescencji rentgenowskiej S1 Titan firmy Bruker

Fig. 1. X-Ray fluorescence spectrometer, S1Titan by Bruker

Próbki skał do przeprowadzenia dokładnych analiz zostały pobrane z całych rdzeni wiertniczych. Od rdzeni odcięto niewielki fragment (pas) o długości 0,5 metra, który następnie wysuszono, skruszono, skwartowano, a część przeznaczoną na analizy XRF domielono w młynku planetarnym dla uzyskania jednakowej wielkości ziaren. Tak przygotowany materiał został zagęszczony w pojemnikach pomiarowych i poddany badaniom. Opisane podejście pozwala na uzyskanie dokładnej uśrednionej informacji z interwału 0,5 metra, co zostanie wykorzystane do kalibracji wyników z pomiarów zwiercin otrzymywanych podczas realizacji kolejnych otworów wiertniczych w warstwach czerwonego spągowca. Próbki zwiercin pobierane są w różnych interwałach, np. co 2 lub co 5 metrów, w zależności od zmienności litologicznej lub kąta wiercenia. Dla jednorodności i dokładności wyników również zwierciny muszą być poddane suszeniu, mieleniu i podobnemu zagęszczeniu co próbki wzorcowe.

\section{Wyniki badań}

Przedstawione w pracy wyniki badań oparte są na pomiarach próbki wzorcowej oraz pomiarach dwudziestu próbek pobranych z rdzeni podczas realizacji otworu wiertniczego w obrębie warstw piaskowców czerwonego spągowca. Próbka wzorcowa SMA-1399 była systematycznie analizowana aparatem XRF. Istotną zmianę rezultatów zauważono po dwóch latach intensywnej eksploatacji sprzętu. Próbki piaskowców analizowano zarówno przenośnym spektrometrem XRF, jak i metodami laboratoryjnymi - spektrometrii emisyjnej i masowej ze wzbudzeniem w plazmie indukcyjnie sprzężonej (ICP-OES/MS). Wykonane badania pozwoliły uzyskać wykresy korelacyjne, na podstawie których stworzono wzory umożliwiające przeprowadzenie dokładnej kalibracji aparatu lub otrzymanych wyników.

\section{Kalibracja korygująca spadek intensywności lampy}

W roku 2017, po naprawie spektrometru XRF, wykonano serie pomiarów próbki wzorcowej, wyniki przedstawiono na tle wartości odczytanych z certyfikatu załączonego do próbki testowej. Pomiary przeprowadzono z ustawieniem czasu pomiarowego na 30 sekund dla pierwszej i drugiej fazy. W pierwszej fazie mierzone są pierwiastki ciężkie, po czym w fazie drugiej - lekkie (główne). Średnia z kilku pomiarów została przedstawiona w tabeli 1: pomiar z 2017 roku. Wyniki są bardzo zbliżone do referencyjnych. Dla $\mathrm{SiO}_{2}$ wynik był zawyżony o około $1 \%$, dla $\mathrm{Al}_{2} \mathrm{O}_{3}$ - o około $0,5 \%$, w przypadku pozostałych pierwiastków dokładność była znacznie większa. Otrzymane wyniki porównano z pomiarami wykonanymi 2 lata później (pomiar - 2019) przy tych samych ustawieniach urządzenia. Spadek intensywności lampy, skutkujący zaniżeniem wyniku, jest zauważalny dla $\mathrm{SiO}_{2}$ oraz $\mathrm{Al}_{2} \mathrm{O}_{3}$. W stosunku do pomiarów z roku 2017 aparat wskazuje o około $5 \% \mathrm{SiO}_{2}$ oraz o około $1,2 \% \mathrm{Al}_{2} \mathrm{O}_{3}$ mniej w stosunku do wyniku sprzed 2 lat. Również w przypadku $\mathrm{K}_{2} \mathrm{O}$ zanotowano spadek zawartości o około $0,1 \%$. Pozostałe pierwiastki nie wykazały zaniżonych wartości.

Wewnętrzną kalibrację spektrometru przeprowadzono na podstawie otrzymanych wyników w tabeli 1 . Do tego celu 
Tabela 1. Wyniki pomiarów próbki wzorcowej SMA-1399 w roku 2017 oraz w roku 2019

Table 1. Measurement results of the SMA-1399 standard sample in 2017 and 2019

\begin{tabular}{|c|c|c|c|c|c|c|c|c|c|}
\cline { 3 - 9 } \multicolumn{2}{c|}{} & $\mathbf{S i O}_{2}$ & $\mathbf{A l}_{2} \mathbf{O}_{3}$ & $\mathbf{F e}$ & $\mathbf{K}_{2} \mathbf{O}$ & $\mathbf{M n}$ & $\mathbf{N i}$ & $\mathbf{C u}$ & $\mathbf{P b}$ \\
\hline \hline \multirow{4}{*}{ Wzorzec SMA-1399 } & certyfikat & $\mathbf{7 3 , 3 0}$ & $\mathbf{1 2 , 7 1}$ & $\mathbf{1 , 6 8}$ & $\mathbf{4 , 9 9}$ & $\mathbf{0 , 1 0}$ & $\mathbf{0 , 0 0 3 5}$ & $\mathbf{0 , 0 1 9 7}$ & $\mathbf{0 , 0 8 4 1}$ \\
\cline { 2 - 10 } & pomiar-2017 & 74,24 & 13,16 & 1,67 & 4,97 & 0,10 & 0,0038 & 0,0202 & 0,0820 \\
\cline { 2 - 11 } & pomiar-2019 & 69,23 & 11,90 & 1,70 & 4,90 & 0,10 & 0,0040 & 0,0200 & 0,0853 \\
\cline { 2 - 10 } & pomiar-2019* & 73,49 & 12,91 & 1,70 & 4,99 & 0,10 & 0,0035 & 0,0195 & 0,0829 \\
\hline
\end{tabular}

$2019^{*}$ - pomiar po wprowadzeniu współczynników kalibracyjnych do spektrometru. Wyniki przedstawione w procentach wagowych $2019^{*}$ - measurement after calibration coefficients application in the spectrometer. Results presented in percent by weight

w oprogramowaniu urządzenia wprowadzono obliczone współczynniki dla krzemu, glinu oraz potasu, tworząc w metodzie pomiarowej dodatkowy moduł uwzględniany podczas pomiarów (rys. 2A). Ważne jest, aby odznaczyć opcję „normalizowanie”, która uwzględnia zadane współczynniki również przy pomiarach pozostałych pierwiastków. Z odznaczoną funkcją poprawiamy wyniki tylko dla trzech zadanych pierwiastków. Po zapisaniu programu należy go wybrać z listy dostępnych opcji, symbol ,"* przy nazwie metody na rysunku 2B oznacza dołączenie kalibracji wewnętrznej do aktualnie prowadzonych pomiarów. W każdej chwili można ją dezaktywować lub zmienić na inną kalibrację. W wierszu pomiar - 2019* (tabela 1) przedstawiono wyniki pomiarów z urządzenia z zastosowaniem nowych współczynników kalibracyjnych.

\section{Kalibracja obniżonych udzialów procentowych pierwiastków lekkich (Si, Al)}

Pomiary 20 próbek piaskowców czerwonego spągowca zostały wykonane w roku 2019 (w czasie, kiedy intensywność lampy obniżyła się o 5\% dla krzemu w stosunku do pomiarów nowym urządzeniem) i skalibrowane w odniesieniu do dokładnych badań laboratoryjnych. Pomiary wykonywane w przyszłości (w momencie, kiedy intensywność lampy ponownie się obniży) będą musiały być kalibrowane w sposób przedstawiony powyżej, z uwzględnieniem pomiarów z roku 2019 jako referencyjnego. Zapewni to dokładność wyników i pozwoli na ich wykorzystanie w modelowaniu składu mineralogicznego skał mierzonych w przyszłości. Kalibrowanie obecnych wyników do pomiarów z roku 2017 nie byłoby prawidłowe.

Do kalibracji wyników dla utworów czerwonego spągowca wykonano 20 pomiarów składu chemicznego skał w akredytowanym laboratorium ACTLABS. Badania przeprowadzono na urządzeniach stacjonarnych przy wykorzystaniu metod spektrometrii emisyjnej i masowej ze wzbudzeniem w plazmie indukcyjnie sprzężonej (ICP-OES/MS). Do wykonania analiz chemicznych próbki stapiano z tetraboranem litu (FUS-ICP). Wartości bezwzględne dla pierwiastków lekkich (krzemu i glinu) są zaniżone w pomiarach z wykorzystaniem ręcznego urządzenia XRF

A)

\begin{tabular}{|c|c|c|}
\hline \multicolumn{3}{|c|}{ SiO2 time } \\
\hline El & Offset & Slope \\
\hline $\mathrm{Mg}$ & 0.0000 & 1.0000 \\
\hline Al & 0.0000 & 1.0681 \\
\hline $\mathrm{Si}$ & 0.0000 & 1.0587 \\
\hline P & 0.0000 & 1.0000 \\
\hline s & 0.0000 & 1.0000 \\
\hline $\mathrm{Cl}$ & 0.0000 & 1.0000 \\
\hline $\mid \begin{array}{l}K \\
r_{0}\end{array}$ & $\begin{array}{l}0.0000 \\
n ח \cap n\end{array}$ & $\begin{array}{l}1.0190 \\
1 \mathrm{nnnn}\end{array}$ \\
\hline
\end{tabular}

OK

$\sqsubset$ Normalize

OK

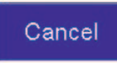

B)
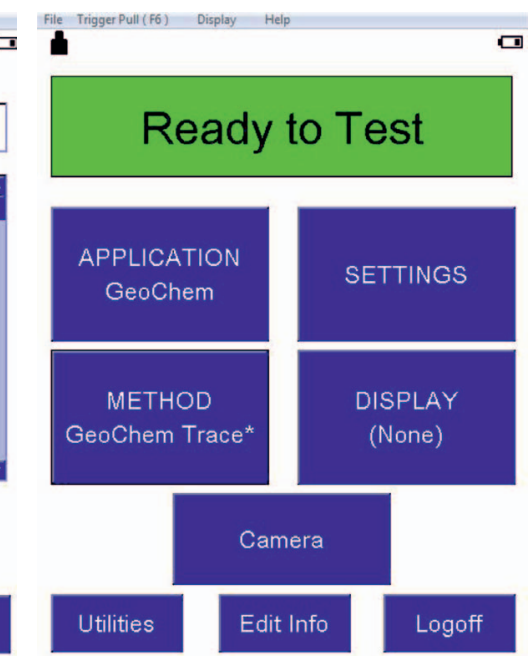

Rys. 2. Okna ustawienia spektrometru; A - okno kalibracji wybranej metody, ustawienie „offsetu” oraz ,slope” otrzymanych z wykresów korelacyjnych; B - gwiazdka przy nazwie metody informuje o wprowadzeniu dodatkowych współczynników kalibracyjnych

Fig. 2. Spectrometer settings window; A - calibration window, setting the offset and slope parameters; B - an asterisk next to the method informs hat additional calibration coefficients have been applied

(przy analizie skał sproszkowanych), ale zmienność ich zawartości jest zachowana. Pozostałe składniki chemiczne z pomiarów XRF, potrzebne do zbudowania modeli litologicznych, charakteryzują się wysoką korelacją. Pierwiastki ciężkie, w tym żelazo $\left(\mathrm{Fe}_{2} \mathrm{O}_{3}\right)$, powinny wykazywać się zarówno wysoką korelacją, jak i dokładnością wyników. Poniżej przedstawiono wyniki pomiarów dla krzemu $\left(\mathrm{SiO}_{2}\right)$, glinu $\left(\mathrm{Al}_{2} \mathrm{O}_{3}\right)$, wapnia $(\mathrm{CaO})$, potasu $\left(\mathrm{K}_{2} \mathrm{O}\right)$ oraz żelaza $\left(\mathrm{Fe}_{2} \mathrm{O}_{3}\right)$. Dla każdego pierwiastka utworzono wykresy korelacyjne oraz wykresy głębokościowe, odpowiadające profilowaniu z zatajonymi głębokościami poboru próbek (skala pionowa od 1 do 20 pkt). Wykresy korelacyjne pozwoliły na otrzymanie wzorów regresji wykorzystywanych do kalibracji wyników. Otrzymane współczynniki można wprowadzić bezpośrednio do oprogramowania spektrometru, jak przedstawiono to na rysunku 2 (,offset" i ,slope”). W celu większej kontroli oraz możliwości wykorzystania współczynników uwzględniających starzenie się lampy rentgenowskiej w kalibracji wewnętrznej - kalibracja na wpływ mielenia próbek stosowana jest na danych pobranych z urządzenia. 

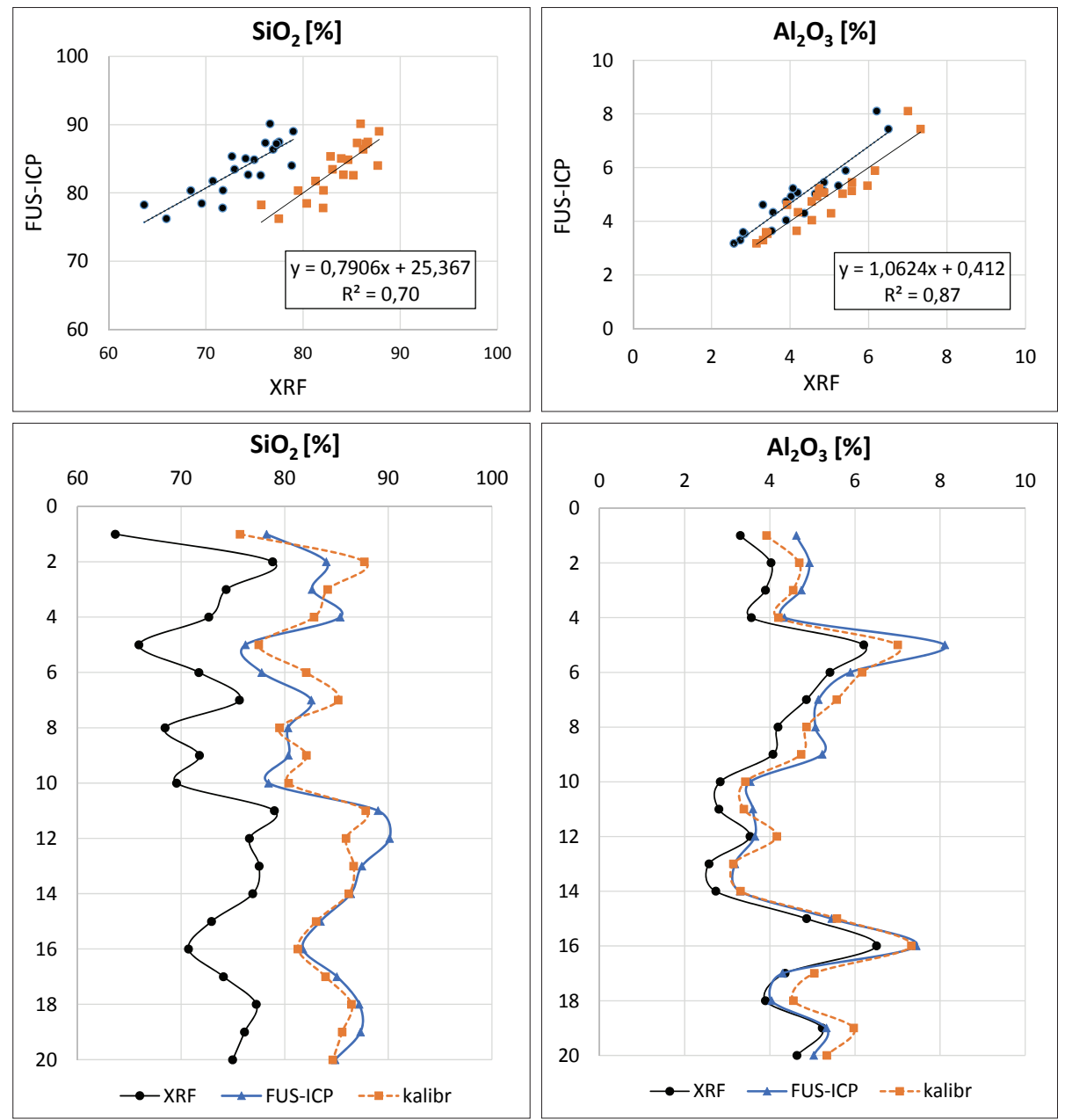

Rys. 3. Porównanie wyników pomiarów $\mathrm{SiO}_{2} \mathrm{i} \mathrm{Al}_{2} \mathrm{O}_{3}$ analizowanych metodą FUS-ICP vs XRF przed i po kalibracji. Wykresy dolne - profile głębokościowe dla wybranych 20 punktów pomiarowych

Fig. 3. Comparison of $\mathrm{SiO}_{2}$ and $\mathrm{Al}_{2} \mathrm{O}_{3}$ measurement results, analysed by FUS-ICP vs $\mathrm{XRF}$ before and after calibration. Bottom charts - depth profiles of chosen 20 measurement points

Do wprowadzania współczynników kalibracyjnych stosuje się oprogramowanie MS Excel lub ProGeo.

Rysunek 3 przedstawia wyniki pomiarów dla krzemu oraz glinu. Są to pierwiastki lekkie, których wyniki cechują się większymi błędami pomiarowymi w stosunku do pierwiastków o większej masie atomowej. Wyniki pomiarów przenośnym aparatem XRF w przypadku krzemu są znacznie zaniżone, co jest spowodowane wykonywaniem pomiarów na próbce sproszkowanej, cechującej się niższą gęstością niż skała przed zmieleniem. Na wykresach przedstawiono korelację pomiarów laboratoryjnych z pomiarami przenośnym aparatem XRF (niebieskie punkty), jak również kolorem pomarańczowym przedstawiono korelację badań laboratoryjnych z pomiarami XRF po kalibracji. Na rysunku 4 zestawiono pomiary dla wapnia, potasu oraz żelaza. W tym przypadku współczynniki korelacji oraz dokładność obu metod są bardzo wysokie. Dla większości próbek kalibracja pierwiastków ciężkich nie jest wymagana.

\section{Wnioski}

W artykule zostały przedstawione możliwości wewnętrznej kalibracji spektrometru XRF S1 Titan oraz zewnętrznej kalibracji wyników. Określono i zastosowano współczynniki kalibracyjne uwzględniające wpływ starzenia się lampy rentgenowskiej oraz współczynniki kalibracyjne pozwalające uzyskać zawartości pierwiastków odpowiadające dokładnym badaniom laboratoryjnym. W pierwszym przypadku współczynniki kalibracyjne zaimplementowano bezpośrednio w urządzeniu, natomiast kalibracja wyników pomiarów próbek została wzięta pod uwagę w oprogramowaniu zewnętrznym. Wykonywanie pomiarów próbek testowych w przyszłości pozwoli na uwzględnianie spadku intensywności lampy i utrzymywanie wyników na jednakowym poziomie. Spadek zawartości pierwiastków został obecnie zauważony dla krzemu, glinu oraz potasu. $\mathrm{Na}$ próbkach skał czerwonego spągowca $\mathrm{z}$ dokładnie określonym składem chemicznym mogą zostać wykonane badania mineralogiczne oraz zbudowane modele łączące skład chemiczny z mineralogicznym. Tak przygotowane modele będą aktualne do momentu zmiany intensywności lampy. $\mathrm{Z}$ tego powodu ważne jest utrzymywanie nowych wyników na podobnym poziomie w celu wykorzystywania otrzymanych modeli. Wykonane prace stanowią ważny wkład w zachowanie wysokiej jakości wyników dla pomiarów składu chemicznego z przenośnej aparatury XRF. Jest to bardzo istotne także ze względu na dalsze zastosowanie tych pomiarów do budowy modeli mineralogicznych i litologicznych wykorzystywanych powszechnie $\mathrm{w}$ interpretacji profilowań geofizyki wiertniczej.

Artykuł powstał na podstawie pracy statutowej pt.: Reinterpretacja krzywych geofizyki otworowej na podstawie badań rdzeni i zwiercin - praca INiG - PIB na zlecenie MNiSW; nr zlecenia: 0051/ SW/2019, nr archiwalny: DK-4100-0041/2019.

\section{Literatura}

Bruker Corporation. <http://www.bruker.com> (dostęp: lipiec 2014). Kowalska S., 2013. Określanie ilościowego składu mineralnego skał zawierających minerały ilaste metodą Rietvelda. Nafta-Gaz, 12: 887-893. Kowalska S., Kubik B., Skupio R., Wolański K., 2018. Rekonstrukcja profilu litologicznego na podstawie wyników pomiarów składu chemicznego rdzeni wiertniczych i próbek okruchowych. Materialy 

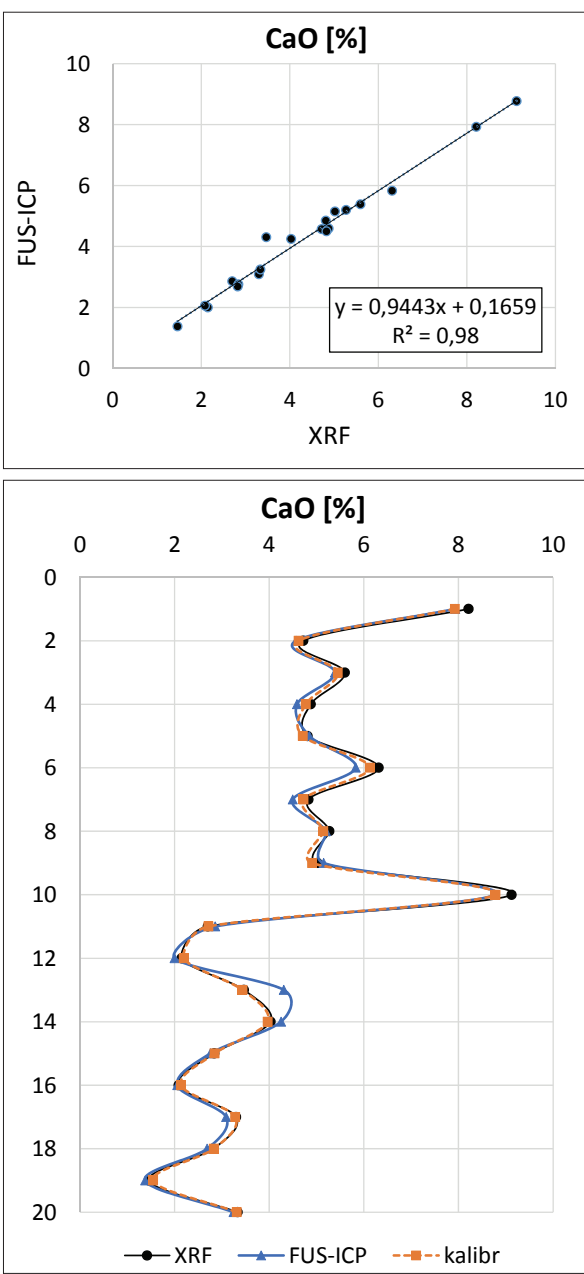
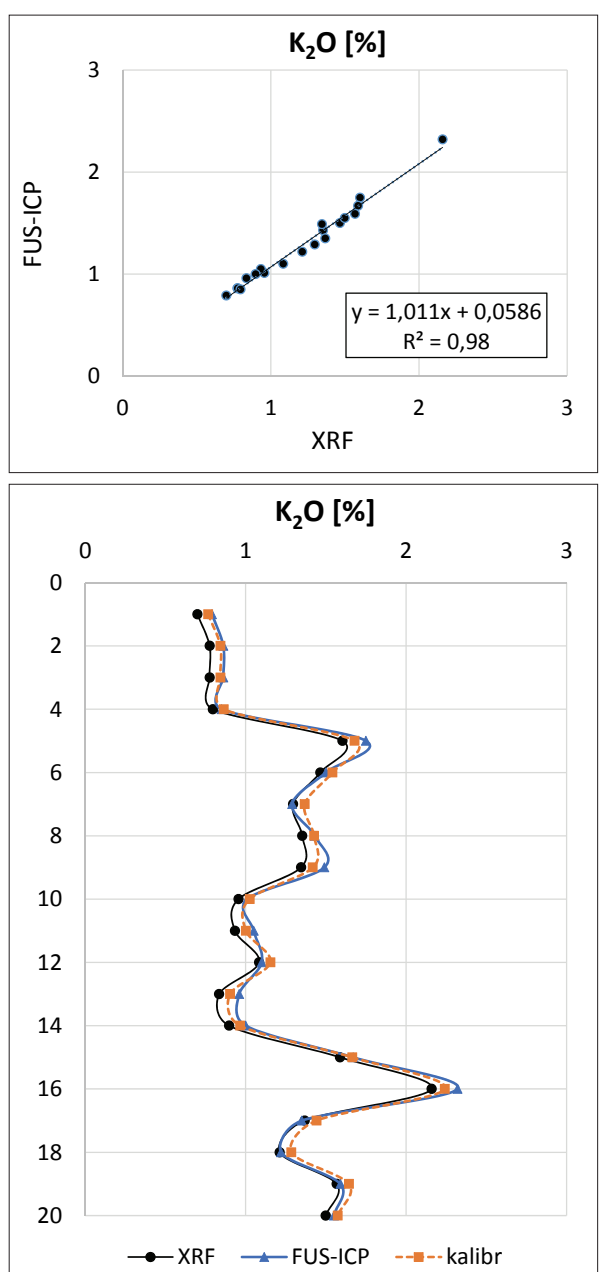
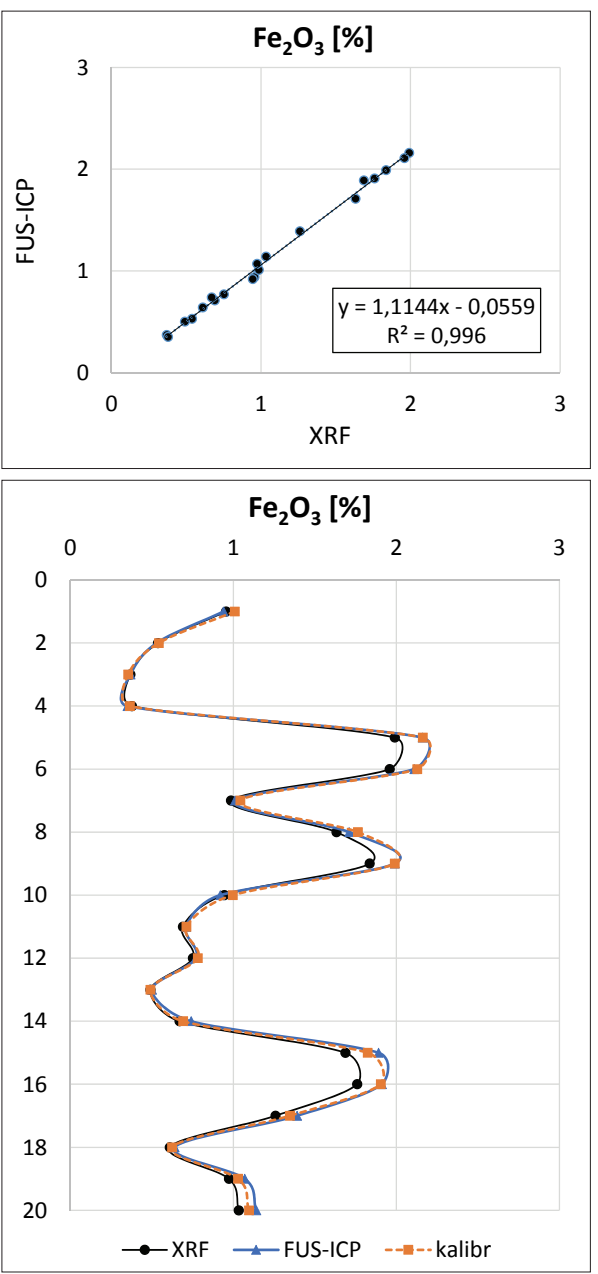

Rys. 4. Porównanie wyników pomiarów $\mathrm{CaO}, \mathrm{K}_{2} \mathrm{O}$ i $\mathrm{Fe}_{2} \mathrm{O}_{3}$ analizowanych metodą FUS-ICP vs XRF. Wykresy górne - korelacja wyników; wykresy dolne - profile głębokościowe wybranych 20 punktów pomiarowych dla wyników przed i po kalibracji

Fig. 4. Comparison of $\mathrm{CaO}, \mathrm{K}_{2} \mathrm{O}$ and $\mathrm{Fe}_{2} \mathrm{O}_{3}$ measurement results, analysed by the FUS-ICP vs XRF method. Top charts - correlation of results; bottom charts - depth profiles of chosen 20 measurement points for results before and after calibration

konferencyjne Międzynarodowej Konferencji Naukowo-Technicznej Geopetrol 2018. Wyd. Instytut Nafty i Gazu - PIB, Kraków: 115-121.

Loubser M., Verryn S., 2008. Combining XRF and XRD analyses and sample preparation to solve mineralogical problems. South African Journal of Geology, 111(2-3): 229-238. DOI: 10.2113/ gssajg.111.2-3.229.

Mehranian A., Ay M.R., Alam N.R., Zaidi H., 2010. Quantifying the effect of anode surface roughness on diagnostic $\mathrm{x}$-ray spectra using Monte Carlo simulation. Medical Physics, 37(2): 742-752.

Ogburn D., Sillar B., Sierra J.C., 2012. Evaluating effects of chemical weathering and surface contamination on the in situ provenance analysis of building stones in the Cuzco region of Peru with portable XRF. Journal of Archaeological Science, 40(4): 1823-1837.

Panalytical. <http://www.panalytical.com/XRFtubes> (dostęp: maj 2019). Skupio R., 2014. Wykorzystanie przenośnego spektrometru XRF do pomiarów składu chemicznego skał. Nafta-Gaz, 11: 771-777.

Spellman High Voltage Electronics Corporation. Application notes - X-ray generators, Common X-ray tube failure modes. AN-02. <http://www. spellmanhv.com> (dostęp: maj 2019).

Wieczorek A., 2012. Ocena możliwości wykorzystania techniki spektrometrii rentgenowskiej z dyspersją fali do badania zawartości szkodliwych i kancerogennych metali ciężkich w produktach naftowych. Nafta-Gaz, 10: 699-707.

Zagórska U., Gąsior I., Orzechowski M., 2016. Ocena możliwości budowy modelu geologiczno-geofizycznego dla utworów czerwonego spągowca z rejonu rowu Grodziska. Nafta-Gaz, 11: 901-909. DOI: 10.18668/NG.2016.11.02

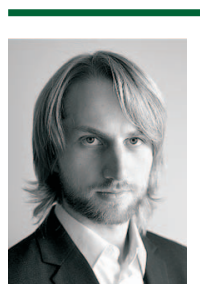

Mgr inż. Rafał SKUPIO

Asystent w Zakładzie Geofizyki Wiertniczej

Instytut Nafty i Gazu - Państwowy Instytut Badawczy ul. Lubicz $25 \mathrm{~A}$

31-503 Kraków

E-mail: rafal.skupio@inig.pl

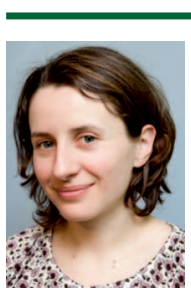

Mgr Urszula ZAGÓRSKA

Asystent w Zakładzie Geofizyki Wiertniczej

Instytut Nafty i Gazu - Państwowy Instytut Badawczy ul. Lubicz 25 A

31-503 Kraków

E-mail:urszula.zagorska@inig.pl

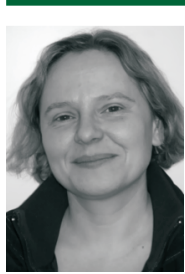

Dr Sylwia KOWALSKA

Adiunkt w Zakładzie Geofizyki Wiertniczej

Instytut Nafty i Gazu - Państwowy Instytut Badawczy ul. Lubicz $25 \mathrm{~A}$

31-503 Kraków

E-mail: sylwia.kowalska@inig.pl 